WMJ (Warmadewa Medical Journal), Vol. 6 No. 2 November 2021, Hal. 57-60

\title{
Microbial Pattern and Antibiotic Sensitivity Test Among Eye In- fection Patients at Bali Mandara Eye Hospital Bali
}

\author{
Pande Putu Ayu Patria Dewi ${ }^{1}$, Moh Fairuz Abadi ${ }^{2}$ \\ ${ }^{1,2,}$ Wira Medika Diploma 3 Technology of Laboratory. ${ }^{1}$ \\ Email ${ }^{1}$ : patriadewi@gmail.com
}

\begin{abstract}
Infection disease of the eye is usually found in health care facilities and can be caused by viral, bacterial, parasites, and fungi. Bali Mandara Eye Hospital was a special hospital for eye disease in Bali. In this hospital, infectious disease of the eye is dominated by bacterial conjunctivitis, viral conjunctivitis, corneal ulcer, and endophthalmitis. This study was a retrospective descriptive study using patients taking eye underground culture in Bali Mandara Eye Hospital, and samples were taken from 2019 till 2020. It can be seen that was found seven microbes and dominated disease was corneal ulcer 26 sample (86\%), followed by endophthalmitis 4 sample (14\%). The most microba were Pseudomonas aeruginosa. Pseudomonas aeruginosa was found resistant to almost all antibiotics and sensitive to levofloxacin, gentamycin, and ceftazidime.
\end{abstract}

Keywords: infection, eye, culture, antibiotics

\section{Abstrak}

[Pola Kuman dan Antibiotika Sensitivitas Tes Pada Penyakit Infeksi Mata di Rumah Sakit Mata Bali Mandara]

Penyakit infeksi pada mata merupakan masalah yang sering dijumpai pada fasilitas kesehatan. Infeksi pada mata dapat disebabkan oleh virus, bakteri, parasit,dan jamur. Rumah Sakit Mata Bali Mandara merupakan salah satu rumah sakit khusus mata yang dimiliki oleh Provinsi Bali. Penyakit infeksi di Rumah Sakit Mata Bali Mandara didominasi oleh konjungtivitis bakteri, konjungtivitis virus, ulkus kornea, dan endoftalmitis Penelitian ini merupakan penelitian deskriptif retrospektif dengan sampel pemeriksaan kultur sekret mata yang dilakukan di Rumah Sakit Mata Bali Mandara tahun 2019 hingga 2020. Penelitian ini mendapatkan hasil distribusi kuman pada pasien penyakit infeksi mata di Rumah Sakit Mata Bali Mandara sebanyak 7 jenis kuman dengan didominasi oleh penyakit ulkus kornea sebanyak 26 sampel $(86 \%)$ diikuti dengan penyakit endophtalmitis sebanyak 4 sampel (14\%). Bakteri penyebab terbanyak adalah Pseudomonas aeruginosa. Pseudomonas aeruginosa resisten pada sebagian besar tipe antibiotika yang diujikan dan hanya sensitif pada levofloxacin, gentamicin dan ceftazidime.

Kata Kunci: infeksi,mata,kultur,antibiotika

\section{INTRODUCTION}

Infection of the eye is usually found in health care facilities and can be caused by viral, bacterial, parasites, and fungil. The most common form of eye infections was conjunctivitis, endophthalmitis, and corneal ulcer. Conjunctivitis in 2009 was a top ten type of infectious eye diseases ${ }^{2}$. The eye's infection is caused by bacteria mostly caused by Haemophilus influenza, Streptococcus pneumonia, Staphylococcus aureus, and Pseudomonas aeruginosa ${ }^{3}$. Treatment for patients with infectious eye diseases is usually by antibiotics, and antibiotic resistance can occur if given not according to the culture or dosage $\mathrm{t}^{4}$. Antibiotic resistance occurs when treatment is not achieved, and the patient does not require recovery.

Bali Mandara Eye Hospital is a government eye hospital in Bali, and infection cases in the eye were bacterial conjunctivitis, viral conjunctivitis, corneal ulcer, and endophthalmitis. An eye disease, especially a corneal ulcer, can cause impaired visual activity and irreversible blindness if not received prompt and effective treatment. 


\section{METHODS}

This study was a retrospective descriptive study with patients who examined the eye culture in Bali Mandara Eye Hospital. The samples were taken from 2019 till 2020. Data of culture results and antibiotic sensitivity tests were collected from the medical record. Data are presented in tabular form.

\section{RESULTS}

This study found seven microbes, and the dominant disease was corneal ulcer with 26 sample $(86 \%)$ followed by 4 samples of endophthalmitis (14\%). The characteristics of microbes in Bali Mandara Eye Hospital from 2019 until 2020 are presented in Table 1.

Tabel 1 Charateristic of microbes in Bali Mandara Eye Hospital During 2019-2020

\begin{tabular}{lll}
\hline \multirow{2}{*}{ Microbes } & \multicolumn{2}{c}{ Eye Secret Culture } \\
\cline { 2 - 3 } & $\mathrm{N}$ & $\%$ \\
\hline Moraxella Spp & 1 & 3,3 \\
Streptococcus spp & 3 & 10 \\
Pseudomonas aeruginosa & 6 & 20 \\
Staphylococcus spp & 3 & 10 \\
Staphylococcus aureus & 1 & 3,3 \\
Enterobacter spp & 1 & 3,3 \\
Klebsiella spp & 1 & 3,3 \\
No growth & 14 & 46 \\
\hline Total & 30 & 100 \\
\hline
\end{tabular}

Antibiotics sensitivity test for each microbe is shown in table 2 . Table 2 shows an antibiotics sensitivity test after being carried out with specific antibiotics disc that matched with the isolate. S percent describes the percentage of isolate sensitivity to the antibiotics. Red color represents sensitivity $0-40 \%$, yellow color represents sensitivity $40-80 \%$, and green color more than $80 \%$.

\section{DISCUSSION}

This study was the first study that examined microbial patterns and antibiotics sensitivity tests in Bali Mandara Eye Hospital. This study found that the most common infectious eye disease was a corneal ulcer. It is different from studies conducted by Ramesh et al. in India, which found the most common infectious disease of the eye were adnexa infection followed by corneal ulcer. $^{5}$

In this study, the most common bacteria that cause eye infection were gram -negative bacteria; this is in contrast with the study in 2015 conducted by Shiferaw et al., which found that the cause of eye infection was gram-positive bacteria dominated by Coagulase-negative staphylococci. ${ }^{6}$

The study formed by Atmawati et al. in Banjarmasin in 2017 found five types of microbes: Staphylococcus aureus, Staphylococcus epidermidis, Staphylococcus saprophyticus, Streptococcus $s p$., and Escherichia coli ${ }^{2}$. However, in this study, we found Pseudomonas aeruginosa, Streptococcus spp, and Staphylococcus spp. Moraxella spp, Staphylococcus spp, Staphylococcus aureus, Enterobacter spp, and Klebsiella spp were found in a small percentage. Atmawati et al. found corneal ulcers and endophthalmitis as infectious eye diseases that appear in their samples.

Moraxella spp was sensitive to almost all antibiotics and resistant to Cefotaxime, Ceftriaxone, and cefixime. Streptococcus spp is sensitive to almost all antibiotics and resistant to gentamycin. Pseudomonas aeruginosa, Staphylococcus spp, and Staphylococcus aureus were found resistant to almost all antibiotics. Although Klebsiella spp was sensitive to almost all antibiotics, it is resistant to Amoxicillin, Ampicillin, and Sulphamethoxazole. This result is different from studies conducted by Shiferaw et al. which found all bacteria gram-positive sensitive to Vancomycin and resistant to Amoxicillin while bacteria gram-negative found resistant to Tetracycline, Norfloxacin, Ceftriaxone, and Ciprofloxacin ${ }^{6}$. The results were different may be caused by temperature, environment, and used topical antibiotics by a patient. Antibiotic resistance may 
WMJ (Warmadewa Medical Journal), Vol. 6 No. 2, November 2021, Hal. 59

be caused by decreased drug efficacy be- drugs without prescription ${ }^{6}$.

cause of improper use, and patients can buy

Table 2. Antibiotics Sensitivity Test in Bali Mandara Eye Hospital During 2019-2020

\begin{tabular}{lllllll}
\hline Microbes & Amoxycilin & Ampicilin & $\begin{array}{l}\text { Chloram- } \\
\text { phenicol }\end{array}$ & $\begin{array}{l}\text { Ciprofloxa- } \\
\text { cine }\end{array}$ & $\begin{array}{l}\text { Doxycy- } \\
\text { cline }\end{array}$ & $\begin{array}{l}\text { Eryrthrom } \\
\text { icin }\end{array}$ \\
\hline & $\% \mathrm{~S}$ & $\% \mathrm{~S}$ & $\% \mathrm{~S}$ & $\% \mathrm{~S}$ & $\% \mathrm{~S}$ & $\% \mathrm{~S}$ \\
\hline $\begin{array}{l}\text { Moraxella Spp } \\
\text { Streptococcus spp }\end{array}$ & 100 & & 100 & 100 & & \\
$\begin{array}{l}\text { Pseudomonas } \\
\text { aeruginosa }\end{array}$ & 0 & 100 & 100 & 66.6 & 600 & 0 \\
$\begin{array}{l}\text { Staphylococcus } \\
\text { spp }\end{array}$ & 0 & 0 & 0 & 66.6 & 0 & 33.3 \\
$\begin{array}{l}\text { Staphylococcus } \\
\text { aureus }\end{array}$ & 0 & 0 & 33.3 & 33.3 & 33.3 & 0 \\
$\begin{array}{l}\text { Enterobacter spp } \\
\text { Klebsiella spp }\end{array}$ & 0 & 0 & 100 & 0 & 0 & 0 \\
\hline
\end{tabular}

\begin{tabular}{|c|c|c|c|c|}
\hline Microbes & Gentamycine & Sulphamethoxazole & Ceftazidime & Cefotaxime \\
\hline & $\% \mathrm{~S}$ & $\% \mathrm{~S}$ & $\% \mathrm{~S}$ & $\% \mathrm{~S}$ \\
\hline Moraxella Spp & 100 & 0 & & 0 \\
\hline Streptococcus spp & 33.3 & & & \\
\hline Pseudomonas aeruginosa & 100 & 0 & 83.3 & 0 \\
\hline Staphylococcus spp & 100 & 33.3 & & 33.3 \\
\hline Staphylococcus aureus & 0 & & & 0 \\
\hline Enterobacter spp & & 0 & 100 & 0 \\
\hline Klebsiella spp & 100 & 0 & 100 & 100 \\
\hline
\end{tabular}

\begin{tabular}{llllll}
\hline Microba & Tetracycline & Cephazoline & Amikacin & Neomycin & Ceftriaxone \\
\hline & $\% \mathrm{~S}$ & $\% \mathrm{~S}$ & $\% \mathrm{~S}$ & $\% \mathrm{~S}$ & $\% \mathrm{~S}$ \\
\hline $\begin{array}{l}\text { Moraxella Spp } \\
\text { Streptococcus spp }\end{array}$ & 100 & & & & \\
$\begin{array}{l}\text { Pseudomonas aeruginosa } \\
\text { Staphylococcus spp }\end{array}$ & 0 & 0 & & & \\
Staphylococcus aureus & 100 & 100 & 66.6 & 33.3 & 33.3 \\
Enterobacter spp & & 0 & 100 & 0 & 0 \\
Klebsiella spp & 100 & 100 & 100 & 100 & 100 \\
\hline
\end{tabular}




\begin{tabular}{llllll}
\hline Microbes & Cefixime & Piperacilin & Ofloxacine & Azythromycin & Levofloxacine \\
\hline & $\% \mathrm{~S}$ & $\% \mathrm{~S}$ & $\% \mathrm{~S}$ & $\% \mathrm{~S}$ & $\% \mathrm{~S}$ \\
\hline $\begin{array}{l}\text { Moraxella Spp } \\
\text { Streptococcus spp }\end{array}$ & 0 & 100 & & & \\
Pseudomonas aeruginosa & 0 & & & & \\
Staphylococcus spp & 0 & 83.3 & 83.3 & 16.6 & 83.3 \\
Staphylococcus aureus & 0 & 0 & 33.3 & 33.3 & 33.3 \\
Enterobacter spp & 0 & 0 & 0 & 0 & 0 \\
Klebsiella spp & 100 & 100 & 100 & 0 & 0 \\
\hline
\end{tabular}

\section{CONCLUSION}

This study found that the most infectious disease of the eye found in Bali Mandara Eye Hospital was a corneal ulcer and microbe that mostly caused it was Pseudomonas aeruginosa. Pseudomonas aeruginosa was found resistant to almost all antibiotics and sensitive to levofloxacin, gentamycin dan ceftazidime. This study needs further research by increasing the sample and collaborating with an ophthalmologist clinician.

\section{ACKNOWLEDGE}

For support, the authors acknowledge Bali Mandara Eye Hospital and all ophthalmologists in Bali Mandara Eye Hospital, especially Doctor Ni Made Indah Kencanawati Ophthalmologist.

\section{REFERENCES}

1. Watson S, Cabrera-Aguas M, Khoo P. Common eye infections. Aust Prescr. 2018;41(3):67-72.

2. Atmawati TU, Faisal MA, Rahmiati R. Pola Kepekaan Isolat Bakteri Aerob pada Konjungtivitis Terhadap Antibiotik Terpilih di Poliklinik Mata RSUD Ulin Banjarmasin. Berkala
Kedokteran. 2017;13(1);2; 15-2

3. Irene Angelika, Fredine Rares JP. Identifikasi Bakteri Aerob Pada Penderita Infeksi Mata Luar di RSU GMIM Pancaran Kasih Manado. J eBiomedik. 2020;8(1):46-54 eISSN 2337-3302

4. Brunner R. A. Kramer, W. BehrensBaumann (eds): Antiseptic Prophylaxis and Therapy in Ocular Infections: Principles, Clinical Practice and Infection Control. Graefe's Arch Clin Exp Ophthalmol. 2003;(3):145190.

5. Ramesh S, Ramakrishnan R, Jayahar Bharathi M, Amuthan M, Viswanathan S. Prevalence of bacterial pathogens causing ocular infections in South India. Indian J Pathol Microbiol. 2010:53;281-6.

6. Shiferaw B, Gelaw B, Assefa A, Assefa Y, Addis Z. Bacterial isolates and their antimicrobial susceptibility pattern among patients with external ocular infections at Borumeda hospital, Northeast Ethiopia. BMC Ophthalmol. 2015;15:103. 